\title{
Impact of Mustard Seed Meal Applications on Direct-Seeded Cucurbits and Weed Control
}

\author{
Charles L. Webber III ${ }^{1}$, Paul M. White Jr. ${ }^{1}$, Rick A. Boydston ${ }^{2} \&$ James W. Shrefler ${ }^{3}$ \\ ${ }^{1}$ USDA, Agriculture Research Service, Sugarcane Research Unit, Houma, LA, USA \\ ${ }^{2}$ USDA, Agriculture Research Service, Grain Legume Genetics Physiology Research, Prosser, WA, USA \\ ${ }^{3}$ Extension Service, Oklahoma State University, Durant, OK, USA \\ Correspondence: Charles L. Webber III, USDA, Agriculture Research Service, Sugarcane Research Unit, Houma, \\ LA 70360, USA. E-mail: chuck.webber@ars.usda.gov
}

Received: June 8, 2017

doi:10.5539/jas.v9n8p81

\author{
Accepted: July 4, 2017 Online Published: July 15, 2017 \\ URL: https://doi.org/10.5539/jas.v9n8p81
}

\begin{abstract}
Weed control in organic production systems can be a labor intensive and expensive process. Mustard seed meal (MSM) is phytotoxic and a potential pre-emergent and preplant-incorporated organic herbicide for controlling germinating and emerging weed seedlings: unfortunately, MSM may also adversely impact seedling survival of certain direct-seeded vegetable crops. Field research was conducted in southeast Oklahoma (Lane, OK) to determine the phytotoxic impact of MSM on indigenous weeds and seedling establishment of cantaloupe (Cucumis melo L.) var. 'PMR-45', cucumber (Cucumis sativus L.) var. 'Marketmore 76', yellow squash (Cucurbita pepo L.) var. 'Crookneck', and watermelon (Citrullus lanatus L.) var. 'Dixie'. The factorial experiment included 2 MSM incorporation levels (no incorporation and incorporation), 2 MSM application rates (2.25 and $4.5 \mathrm{mt} / \mathrm{ha}$ ), 2 application patterns (banded and solid), 2 experimental control treatments (1 for each incorporation method) and four replications. The soil [Bernow fine sandy loam, 0-3\% slope (fine-loamy, siliceous, thermic Glossic Paleudalf)] was prepared for planting by plowing, fertilizing, and forming raised beds. MSM was applied to raised beds $3 \mathrm{~m}$-long on $0.76 \mathrm{~m}$-centers. The banded application produced a $10.2 \mathrm{~cm}$-wide MSM-free area in the bed center where the crop would later be direct-seeded. The MSM was then either left on the surface or incorporated into the top $2.5-5.0 \mathrm{~cm}$ and then direct-seeded with cantaloupe, cucumber, yellow squash, and watermelon. Plant stands and weed control ratings were collected during the experimental period. Twenty-eight days after planting, the entire plot was harvested and the fresh and dry plant weights determined. Although applications of MSM provided sufficient broadleaf, grass, and total weed control, cucurbit establishment and development, the application of MSM at 2.25 and $4.5 \mathrm{mt} /$ ha severely reduced crop establishment of direct-seeded cucurbits. Further research should address banded applications of MSM with either established direct-seeded or transplanted cucurbits and other vegetable crops in the same manner as others have done with corn gluten meal.
\end{abstract}

Keywords: agricultural by-products, certified organic, organic weed control, pestiphytology

\section{Introduction}

\subsection{Organic Weed Control}

Weed control is often considered a major production concern for producers, whether they use conventional (Pimental et al., 2001; Zimdahl, 2002) or organic (McDade \& Christians, 2000; Walz, 2011) production systems. Weed research was rated as the number one priority by organic producers (Walz, 2011). Research has been conducted to develop weed control strategies that would qualify as natural, organic, and/or sustainable (Webber \& Shrefler, 2008). Naturally occurring chemicals found within plants offer an excellent potential source for natural herbicides for weed control in crops (Rice, 1984).

\subsection{Mustard Seed Meal}

Field incorporation of yellow mustard as a cover crop reduced redroot pigweed (Amaranthus retroflexus) germination and establishment, but did not adversely impact green bean (Phaseolus vulgaris) (Haramoto \& Gallandt, 2005). Mustard (Sinapis alba L.) plants contain glucosinolates (Ildikó et al., 2006), mainly in the seeds, which are considered allelopathic compounds (Kobayashi, 2004). Mustard seed is processed for the extraction of 
the seed oil for biodiesel (Ciubota-Rosie et al., 2013; Hoagland et al., 2008) and the manufacture of food condiments (Brown, 1997). In greenhouse weed control research, mustard seed meal (MSM) reduced emergence and development of annual bluegrass (Poа аппиа L.), common chickweed (Stellaria media (L.) Vill.), and creeping woodsorrel (Oxalis corniculata L.) when applied to the soil surface at 113,225 , and $450 \mathrm{~g} / \mathrm{m}^{2}$ (Boydston et al., 2008). Earlywine et al. (2010), in a similar greenhouse experiment with oriental mustard (Brassica juncea (L.) Czern.), determined that 3,360 kg/ha MSM reduced emergence of the following weeds; annual bluegrass (Poa annua L.), large crabgrass (Digitaria sanguinalis L. Scop.), buckhorn plantain (Plantago lanceolate L.), white clover (Trifolium repens L.) and common chickweed (Stellaria media (L.) Vill.).

Field research with MSM from India mustard (Brassica juncea L. Czern.) 'Pacific Gold' and white mustard (Sinapis alba L.) 'IdaGold' significantly reduced emergence and seedling biomass of 4 weed species; Italian ryegrass (Lolium perenne spp. Multiflorum Lam. Husnot), prickly lettuce (Lactuca serriola L.), redroot pigweed (Amaranthus retroflexus L.), and wild oat (Avena fatua L.) (Handiseni et al., 2011). 'IdaGold', a yellow condiment mustard variety, was developed by the Idaho Agricultural Experiment Station and released in 1997 (Brown, 1997). The primary glucosinolate within 'IdaGold' seed meal is glucosinalbin (4-hydroxybenzyl GSL) (Wang et al., 2015). Weed research comparing large crabgrass and palmer amaranth weed control with MSM from two plant sources, 'IdaGold' and 'Pacific Gold", determined 1) that as the rate of MSM increased, the rate of controlled increased, 2) the source of MSM impacted the rate of control for a specific weed, and 3) incorporating the MSM decreased the weed control effectiveness (Wang et al., 2015). Further research determined that redroot pigweed was almost completed killed when treated with 70 or $280 \mathrm{~g} / \mathrm{m}^{2}$ MSM in a greenhouse experiment when 'IdaGold' MSM was applied either PPI, PRE, or at the cotyledon stage (Boydston et al., 2011).

This research evaluated the phytotoxic impact MSM application rates, application methods, and soil incorporation on weed control and cucurbit establishment.

\section{Material and Methods}

\subsection{Land Preparation}

The experiments were conducted in 2007 and 2008 at the Oklahoma State University, Lane Agricultural Center, Lane, OK (lat. $34^{\circ} 17^{\prime} \mathrm{N}$, long. $95^{\circ} 57^{\prime} \mathrm{W}$ ) on a Bernow fine sandy loam, 0-3\% slope (fine-loamy, siliceous, thermic Glossic Paleudalf) soil. Prior to MSM applications and planting, the soil was fertilized and prepared following Oklahoma Cooperative Extension Service recommendations (Motes et al., 2008).

\subsection{Mustard Seed Meal Application}

The experiment was a randomized complete block design (RCBD) with 50 treatments ( 5 cropping options by 10 treatments) and 4 replications. The cropping options included 4 cucurbit crops and a "no-crop" option. The 10 experimental treatments for each cropping option included 3 MSM application rates ( $(0,2.25$ and $4.5 \mathrm{mt} / \mathrm{ha}), 2$ application patterns (banded and solid), and 2 MSM incorporation levels (no incorporation and incorporation). MSM was applied to raised beds $3 \mathrm{~m}$-long on $0.76 \mathrm{~m}$-centers. The banded application produced a $10.2 \mathrm{~cm}$-wide MSM-free area in the bed center where the crop would later be direct-seeded (Webber \& Shrefler, 2006). The MSM was applied by hand using light weight forms to provide the correct application configuration. The MSM was then either left on the surface or incorporated into the top 2.5-5.0 cm with a Littiston ${ }^{\circledR} 6400$ Rolling Cultivator ${ }^{\circledR}$ (Lilliston, Bigham Brothers, Inc., 705 E. Slaton Road, Lubbock, Texas 79452) and then direct-seeded.

\subsection{Planting}

The cucurbits in the experiments were cantaloupe (Cucumis melo L.) var. 'PMR-45' (DeWitt Seed Company, P.O. Box 5556, Norman, OK 73070), cucumber (Cucumis sativus L.) var. 'Marketmore 76' (Burpee Seed Company, W. Atlee Burpee \& Co., 300 Park Avenue, Warminster, PA 18974), yellow crookneck squash (Cucurbita pepo L.) var. 'Crookneck' (Burpee Seed Company, W. Atlee Burpee \& Co., 300 Park Avenue, Warminster, PA 18974), and watermelon (Citrullus lanatus L.) var. 'Dixie' (Burpee Seed Company, W. Atlee Burpee \& Co., 300 Park Avenue, Warminster, PA 18974). Each cucurbit seed type was planted in its own plot but within the same RCBD experiment. The cucurbit seeds were planted on July 23, 2007 and 2008 in the center of each raised bed at the rate of $1 \mathrm{seed} / 14.5 \mathrm{~cm}$ (6.9 seeds/meter) using a Monosem ${ }^{\circledR}$ vacuum planter (Monosem Inc., 1001 Blake St., Edwardsville, KS 66111). The seed were planted at a higher than normal planting rate $(6.9 \mathrm{seeds} / \mathrm{m}$ versus 3.8 seeds $(\mathrm{m}$ ) to better determine the phytotoxicity of the MSM on cucurbits. 


\subsection{Weed Control}

No herbicides, other than the MSM, were applied to the experiments. All the weeds in the cucurbit plots were hand-weeded, while the weeds in the no-crop plantings were allowed to grow to isolate the impact of the MSM treatments on percent weed control. Weed control ratings were collected at 12, 15, and 19 days after planting (DAP). Weed control ratings represent the percent weed control for a treatment compared with the weedy control $(0 \mathrm{mt} / \mathrm{ha} \mathrm{MSM})$. A visual rating system of $0 \%$ to $100 \%$ was used, $0 \%$ representing no weed control and $100 \%$ representing complete weed control. Weed control data were converted using an arcsine transformation to facilitate statistical analysis and mean separation to normalize data within the parameters suggested by Ahrens et al. (1990). Smooth crabgrass [Digitaria ischaemum (Schreb.)] was the primary grass weed which covered approximately $60 \%$ of the total weeds present in the field with less than $1 \%$ consisting of fall panicum (Panicum dichotomiflorum Michx.). Cutleaf groundcherry (Physalis angulata L.) and spiny amaranth (Amaranthus spinosus L.) were the primary broadleaf weeds covering approximately $40 \%$ of the total weeds in the field. Yellow nutsedge (Cyperus esculentus L.) represented less than $1 \%$ of the total weeds and was not evenly distributed across the field.

\subsection{Plant Harvest and Stand Establishment}

At 28 DAP, August 20, 2007 and 2008, the cucurbit plants in each plot were harvested to determine the fresh and dry weights. The oven-dried weights were determined by placing the sample bags in a forced air oven at $66{ }^{\circ} \mathrm{C}$ for $48 \mathrm{hr}$. The plant fresh and dry weights for each plot were then converted to $\mathrm{kg} / \mathrm{ha}$. The percent mortality was determined by comparing the number of plants harvested in each cucurbit crop by the number of plants in the control for that crop.

\subsection{Statistical Analysis}

Except for a year by treatment interaction for the nutsedge weed control, the remainder of the weed control and harvest data will be discussed across years by treatment for each cucurbit crop. The experiment was RCBD with four replications and conducted in 2007 and 2008. All data were subjected to ANOVA and mean separation using LSD with $\mathrm{P}=0.05$ (SAS Inc., SAS, Cary, NC). The percentage weed cover and weed rating data were prepared for analyses using a square root arcsine transformation to normalize the data. Mean differences were determined using the transformed data and the non-transformed data values are reported using the mean differences determined with the transformed data (Ahrens et al., 1990).

\section{Results}

\subsection{Weed Control}

\subsubsection{Broadleaf Weed Control}

MSM applied at $4.5 \mathrm{mt} / \mathrm{ha}$ controlled broadleaf weeds the best when applied at as solid strip application independently of incorporation method (Table 1). Differences among experimental treatments decreased with each successive visual observation from 12 DAP to 19 DAP. The banded application method, leaving a 10.2 $\mathrm{cm}$-wide MSM-free area in the bed center, generally reduced the broadleaf weed control efficacy with greater differences observed between application methods for the non-incorporated compared to the incorporated. 
Table 1. Percentage broadleaf (cutleaf groundcherry and spiny amaranth) weed control as affected by mustard seed meal application rates, application rates, and incorporation averaged across years (2007 and 2008)

\begin{tabular}{|c|c|c|c|c|c|}
\hline \multicolumn{2}{|l|}{ Application } & \multirow{2}{*}{ Incorporation } & \multicolumn{3}{|c|}{ Broadleaf Weed Control } \\
\hline Rate & Method & & 12 DAP & 15 DAP & 19 DAP \\
\hline ---- mt/ha ---- & & & ---- \% ---- & ---- \% ---- & ---- \% ---- \\
\hline 0 & NA & No & $0.0 \mathrm{e}^{\mathrm{z}}$ & $0.0 \mathrm{e}$ & $0.0 \mathrm{c}$ \\
\hline 2.25 & Solid & No & $89.6 \mathrm{c}$ & $85.0 \mathrm{~d}$ & $95.1 \mathrm{a}$ \\
\hline 2.25 & Banded & No & $79.2 \mathrm{~d}$ & $90.1 \mathrm{c}$ & $93.8 \mathrm{a}$ \\
\hline 4.5 & Solid & No & $100.0 \mathrm{a}$ & $98.2 \mathrm{a}$ & $98.2 \mathrm{a}$ \\
\hline 4.5 & Banded & No & $83.3 \mathrm{~d}$ & $84.4 \mathrm{~d}$ & $84.5 \mathrm{~b}$ \\
\hline 0 & NA & Yes & $0.0 \mathrm{e}$ & $0.0 \mathrm{e}$ & $0.0 \mathrm{c}$ \\
\hline 2.25 & Solid & Yes & $94.9 \mathrm{~b}$ & $93.2 \mathrm{abc}$ & $96.6 \mathrm{a}$ \\
\hline 2.25 & Banded & Yes & $91.5 \mathrm{bc}$ & $92.6 \mathrm{bc}$ & $95.1 \mathrm{a}$ \\
\hline 4.5 & Solid & Yes & $100.0 \mathrm{a}$ & $95.8 \mathrm{ab}$ & $97.7 \mathrm{a}$ \\
\hline 4.5 & Banded & Yes & $91.5 \mathrm{bc}$ & $90.4 \mathrm{c}$ & $95.6 \mathrm{a}$ \\
\hline
\end{tabular}

Note. ${ }^{\mathrm{z}}$ Means in a column followed by the same lower case letter are not significantly different at $\mathrm{P} \leq 0.05$, ANOVA.

\subsubsection{Smooth Crabgrass Control}

Although the earliest (12 DAP) smooth crabgrass control ratings were outstanding, 100\% for all treatments receiving MSM except for 91\% smooth crabgrass control for incorporated $2.25 \mathrm{mt} /$ ha solid application, all smooth crabgrass control quickly decreased for the 15 and 19 DAP weed ratings (Table 2). Within the 15 and 19 DAP evaluation dates, smooth crabgrass control generally increased as the application rate increased. The solid application method produced significantly greater smooth crabgrass control than the banded application when the MSM was not incorporated. The same pattern was seen at 19 DAP for the incorporated treatments. Except for the $94 \%$ smooth crabgrass control at $15 \mathrm{DAP}$ for the $4.5 \mathrm{mt} /$ ha solid application without incorporation, smooth crabgrass control was unacceptable at the 15 and 19 DAP evaluations.

Table 2. Smooth crabgrass control as affected by mustard seed meal application rates, application methods, and incorporation averaged across years (2007 and 2008)

\begin{tabular}{|c|c|c|c|c|c|}
\hline \multicolumn{2}{|c|}{ Application } & \multirow{2}{*}{ Incorporation } & \multicolumn{3}{|c|}{ Smooth Crabgrass Control } \\
\hline Rate & Method & & 12 DAP & 15 DAP & 19 DAP \\
\hline ---- mt/ha ---- & & & ---- \% ---- & ---- \% ---- & ---- \% ---- \\
\hline 0 & NA & No & $0.0 c^{z}$ & $0.0 \mathrm{e}$ & $0.0 \mathrm{~h}$ \\
\hline 2.25 & Solid & No & $100.0 \mathrm{a}$ & $62.0 \mathrm{~d}$ & $18.3 \mathrm{f}$ \\
\hline 2.25 & Banded & No & $100.0 \mathrm{a}$ & $77.0 \mathrm{~b}$ & $12.5 \mathrm{~g}$ \\
\hline 4.5 & Solid & No & $100.0 \mathrm{a}$ & $94.0 \mathrm{a}$ & $65.8 \mathrm{a}$ \\
\hline 4.5 & Banded & No & $100.0 \mathrm{a}$ & $62.0 \mathrm{~d}$ & $16.7 \mathrm{fg}$ \\
\hline 0 & NA & Yes & $0.0 \mathrm{c}$ & $0.0 \mathrm{e}$ & $0.0 \mathrm{~h}$ \\
\hline 2.25 & Solid & Yes & $91.0 \mathrm{~b}$ & $67.3 \mathrm{c}$ & $25.0 \mathrm{e}$ \\
\hline 2.25 & Banded & Yes & $100.0 \mathrm{a}$ & $69.2 \mathrm{c}$ & $50.5 \mathrm{c}$ \\
\hline 4.5 & Solid & Yes & $100.0 \mathrm{a}$ & $76.0 \mathrm{~b}$ & $56.0 \mathrm{~b}$ \\
\hline 4.5 & Banded & Yes & $100.0 \mathrm{a}$ & $75.0 \mathrm{~b}$ & $42.5 \mathrm{~d}$ \\
\hline
\end{tabular}

Note. ${ }^{\mathrm{z}}$ Means in a column followed by the same lower case letter are not significantly different at $\mathrm{P} \leq 0.05$, ANOVA.

\subsubsection{Total Weed Control}

Total weed control remained fairly stable across evaluation dates (12, 15, and 19 DAP) with slight increases as the days from application increased (Table 3). The $4.5 \mathrm{mt} /$ ha solid application of MSM that was not incorporated produced the greatest total weed control across all treatments for each evaluation date $(>95 \%)$. 
Table 3. Total (broadleaf, smooth crabgrass and yellow nutsedge) weed control as affected by mustard seed meal application rates, application methods, and incorporation averaged across years (2007 and 2008).

\begin{tabular}{|c|c|c|c|c|c|}
\hline \multicolumn{2}{|c|}{ Application } & \multirow{2}{*}{ Incorporation } & \multicolumn{3}{|c|}{ Total Weed Control } \\
\hline Rate & Method & & 12 DAP & 15 DAP & 19 DAP \\
\hline ---- mt/ha ---- & & & ---- \% ---- & ---- \% ---- & ---- \% ---- \\
\hline 0 & NA & No & $0.0 \mathrm{e}^{\mathrm{z}}$ & $0.0 \mathrm{f}$ & $0.0 \mathrm{~d}$ \\
\hline 2.25 & Solid & No & $81.5 \mathrm{c}$ & $80.0 \mathrm{de}$ & $90.4 \mathrm{~b}$ \\
\hline 2.25 & Banded & No & $75.9 \mathrm{~d}$ & $82.5 \mathrm{~cd}$ & $88.8 \mathrm{~b}$ \\
\hline 4.5 & Solid & No & $98.1 \mathrm{a}$ & $95.6 \mathrm{a}$ & $95.6 \mathrm{a}$ \\
\hline 4.5 & Banded & No & $74.1 \mathrm{~d}$ & $76.3 \mathrm{e}$ & $80.0 \mathrm{c}$ \\
\hline 0 & $\mathrm{NA}$ & Yes & $0.0 \mathrm{e}$ & $0.0 \mathrm{f}$ & $0.0 \mathrm{~d}$ \\
\hline 2.25 & Solid & Yes & $87.8 \mathrm{~b}$ & $86.0 \mathrm{bc}$ & $90.3 \mathrm{~b}$ \\
\hline 2.25 & Banded & Yes & $87.8 \mathrm{~b}$ & $87.0 \mathrm{bc}$ & $90.3 \mathrm{~b}$ \\
\hline 4.5 & Solid & Yes & $89.9 \mathrm{~b}$ & $89.5 \mathrm{~b}$ & $92.4 \mathrm{ab}$ \\
\hline 4.5 & Banded & Yes & $81.1 \mathrm{c}$ & $82.0 \mathrm{~cd}$ & $89.7 \mathrm{~b}$ \\
\hline
\end{tabular}

Note. ${ }^{\mathrm{z}}$ Means in a column followed by the same lower case letter are not significantly different at $\mathrm{P} \leq 0.05$, ANOVA.

\subsubsection{Yellow Nutsedge Control}

Unlike the broadleaf, smooth crabgrass and total weed control data, a significant treatment by year interaction was detected for the yellow nutsedge weed analysis; therefore the data will be discussed by year rather than averaged across years (Tables 4 and 5). Only in 2007, at the 19 DAP evaluation, did the MSM treatments (2.5 and $4.5 \mathrm{mt} / \mathrm{ha}$ ) that were not incorporated have yellow nutsedge weed control ratings at $90 \%$ or greater (Tables 4 and 5). In 2008, the non-incorporated MSM treatments also produced moderate yellow nutsedge control $(79.5 \%$ to $85.0 \%$ ) (Table 5). Except for an $83.3 \%$ yellow nutsedge control for the non-incorporated solid application of $4.5 \mathrm{mt} / \mathrm{ha}$ MSM treatment in 2007 at the 12 DAP evaluation, all the yellow nutsedge ratings for the 12 and 15 DAP ratings were $72 \%$ or less, with most below $50 \%$ control (Tables 4 and 5).

Table 4. Nutsedge weed control as affected by mustard seed meal application rates, application methods, and incorporation in 2007

\begin{tabular}{|c|c|c|c|c|c|}
\hline \multicolumn{2}{|c|}{ Application } & \multirow{2}{*}{ Incorporation } & \multicolumn{3}{|c|}{ Yellow Nutsedge Control } \\
\hline Rate & Method & & 12 DAP & 15 DAP & 19 DAP \\
\hline ---- mt/ha ---- & & & ---- \% ---- & ---- \% ---- & ---- \% ---- \\
\hline 0 & NA & No & $0.0 \mathrm{~g}^{\mathrm{z}}$ & $0.0 \mathrm{~g}$ & $0.0 \mathrm{~d}$ \\
\hline 2.25 & Solid & No & $16.7 \mathrm{ef}$ & $46.7 \mathrm{bc}$ & $94.6 \mathrm{a}$ \\
\hline 2.25 & Banded & No & $10.0 \mathrm{f}$ & $41.0 \mathrm{~cd}$ & $90.0 \mathrm{a}$ \\
\hline 4.5 & Solid & No & $83.3 \mathrm{a}$ & $62.2 \mathrm{a}$ & $94.8 \mathrm{a}$ \\
\hline 4.5 & Banded & No & $72.0 \mathrm{~b}$ & $51.2 \mathrm{~b}$ & $92.0 \mathrm{a}$ \\
\hline 0 & NA & Yes & $0.0 \mathrm{~g}$ & $0.0 \mathrm{~g}$ & $0.0 \mathrm{~d}$ \\
\hline 2.25 & Solid & Yes & $45.5 \mathrm{c}$ & $28.6 \mathrm{f}$ & $28.6 \mathrm{c}$ \\
\hline 2.25 & Banded & Yes & $45.5 \mathrm{c}$ & $47.1 \mathrm{~b}$ & $57.1 \mathrm{~b}$ \\
\hline 4.5 & Solid & Yes & $31.8 \mathrm{~d}$ & $35.7 \mathrm{de}$ & $31.0 \mathrm{c}$ \\
\hline 4.5 & Banded & Yes & $18.2 \mathrm{e}$ & $31.1 \mathrm{ef}$ & $25.1 \mathrm{c}$ \\
\hline
\end{tabular}

Note. ${ }^{\mathrm{z}}$ Means in a column followed by the same lower case letter are not significantly different at $\mathrm{P} \leq 0.05$, ANOVA. 
Table 5. Nutsedge weed control as affected by mustard seed meal application rates, application methods, and incorporation in 2008

\begin{tabular}{|c|c|c|c|c|c|}
\hline \multicolumn{2}{|c|}{ Application } & \multirow{2}{*}{ Incorporation } & \multicolumn{3}{|c|}{ Yellow Nutsedge Control } \\
\hline Rate & Method & & 12 DAP & 15 DAP & 19 DAP \\
\hline ---- mt/ha ---- & & & ---- \% ---- & ---- \% ---- & ---- \% ---- \\
\hline 0 & NA & No & $0.0 \mathrm{e}^{\mathrm{z}}$ & $0.0 \mathrm{f}$ & $0.0 \mathrm{~d}$ \\
\hline 2.25 & Solid & No & $21.5 \mathrm{~d}$ & $51.2 \mathrm{bc}$ & $84.5 \mathrm{a}$ \\
\hline 2.25 & Banded & No & $15.0 \mathrm{~d}$ & $46.0 \mathrm{~cd}$ & $79.5 \mathrm{a}$ \\
\hline 4.5 & Solid & No & $57.0 \mathrm{a}$ & $66.2 \mathrm{a}$ & $81.0 \mathrm{a}$ \\
\hline 4.5 & Banded & No & $47.2 \mathrm{~b}$ & $53.5 \mathrm{~b}$ & $85.0 \mathrm{a}$ \\
\hline 0 & $\mathrm{NA}$ & Yes & $0.0 \mathrm{e}$ & $0.0 \mathrm{f}$ & $0.0 \mathrm{~d}$ \\
\hline 2.25 & Solid & Yes & $31.5 \mathrm{c}$ & $27.6 \mathrm{e}$ & $29.0 \mathrm{c}$ \\
\hline 2.25 & Banded & Yes & $29.8 \mathrm{~cd}$ & $42.2 \mathrm{bc}$ & $55.1 \mathrm{~b}$ \\
\hline 4.5 & Solid & Yes & $30.7 \mathrm{c}$ & $32.7 \mathrm{de}$ & $33.0 \mathrm{c}$ \\
\hline 4.5 & Banded & Yes & $23.0 \mathrm{~d}$ & $29.2 \mathrm{de}$ & $27.1 \mathrm{c}$ \\
\hline
\end{tabular}

Note. ${ }^{\mathrm{z}}$ Means in a column followed by the same lower case letter are not significantly different at $\mathrm{P} \leq 0.05$, ANOVA.

\subsection{Cucurbit Seedling Establishment and Harvest}

The incorporated control treatment $(0 \mathrm{mg} / \mathrm{ha}$ MSM) in each of the seedling types (cantaloupe, cucumber, squash, and watermelon) represented the best stand establishment and therefore were used as the standard for comparison (100\% establishment) (Tables 6, 7, 8, and 9). Also, in each seedling type the non-incorporated control treatment (0 $\mathrm{mg} / \mathrm{ha}$ MSM) had the second highest stand establishment, but significantly less than the incorporated control treatment (0 mg/ha MSM) (Tables 6, 7, 8, and 9). Due to the differences among the seedling types for the various harvest parameters, the impact of the MSM application rates, application methods, and incorporation will be discussed by individual species.

\subsubsection{Cantaloupe}

Cantaloupe seedling development and establishment were severely adversely impacted by the application of MSM to the soil prior to direct-seeding (Table 6). Independent of the application rate and whether the MSM was incorporated or not, the solid application reduced seedling establishment compared to the banded applications (Table 6). In all cases, except one, the average fresh and dry weights of the seedlings were less when the MSM was applied as a solid band.

Table 6. Impact of mustard seed meal applications (MSM) on cantaloupe seedling growth and establishment as affected by mustard seed meal application rates, application methods, and incorporation averaged across 2007 and 2008

\begin{tabular}{|c|c|c|c|c|c|}
\hline \multicolumn{2}{|c|}{ Application } & \multirow{2}{*}{ Incorporation } & \multicolumn{3}{|c|}{ Cantaloupe Seedling Harvest Parameters } \\
\hline Rate & Method & & Fresh Weight & Dry Weight & Establishment \\
\hline ---- mt/ha ---- & & & ---- g/plant ---- & ---- g/plant ---- & ---- \% ---- \\
\hline 0 & NA & No & $1131.4 b^{z}$ & $91.9 \mathrm{~b}$ & $72.2 \mathrm{~b}$ \\
\hline 2.25 & Solid & No & $26.7 \mathrm{~d}$ & $3.7 \mathrm{~d}$ & $2.8 \mathrm{ef}$ \\
\hline 2.25 & Banded & No & $74.7 \mathrm{~d}$ & $9.2 \mathrm{~d}$ & $12.5 \mathrm{de}$ \\
\hline 4.5 & Solid & No & $17.3 \mathrm{~d}$ & $1.8 \mathrm{~d}$ & $2.8 \mathrm{ef}$ \\
\hline 4.5 & Banded & No & $397.8 \mathrm{c}$ & $44.6 \mathrm{c}$ & $44.4 \mathrm{c}$ \\
\hline 0 & $\mathrm{NA}$ & Yes & $1841.0 \mathrm{a}$ & $169.1 \mathrm{a}$ & $100.0 \mathrm{a}$ \\
\hline 2.25 & Solid & Yes & $76.6 \mathrm{~d}$ & $7.9 \mathrm{~d}$ & $5.6 \mathrm{ef}$ \\
\hline 2.25 & Banded & Yes & $426.3 \mathrm{c}$ & $49.9 \mathrm{c}$ & $23.6 \mathrm{~d}$ \\
\hline 4.5 & Solid & Yes & $36.5 \mathrm{~d}$ & $3.6 \mathrm{~d}$ & $1.4 \mathrm{f}$ \\
\hline 4.5 & Banded & Yes & $380.6 \mathrm{c}$ & $35.7 \mathrm{c}$ & $22.2 \mathrm{~d}$ \\
\hline
\end{tabular}

Note. ${ }^{\mathrm{z}}$ Means in a column followed by the same lower case letter are not significantly different at $\mathrm{P} \leq 0.05$, ANOVA. 


\subsubsection{Cucumber}

Cucumber establishment and development were adversely impacted by MSM applications (Table 7). The solid MSM application decreased stand establishment to $7 \%$ or less, and fewer plants compared to the banded application except at the $4.5 \mathrm{mt} / \mathrm{ha}$ application, no incorporation, treatment where neither treatment had any surviving cucumber seedlings (Table 7). Cucumber seedlings fresh and dry weights follow the same general trend seen with the stand establishment, decreasing values with increasing MSM application rates and lower weights when the MSM was applied in a solid versus a banded strip (Table 7).

Table 7. Impact of mustard seed meal applications (MSM) on cucumber seedling growth and establishment as affected by mustard seed meal application rates, application methods, and incorporation averaged across 2007 and 2008

\begin{tabular}{|c|c|c|c|c|c|}
\hline \multicolumn{2}{|c|}{ Application } & \multirow{2}{*}{ Incorporation } & \multicolumn{3}{|c|}{ Cucumber Seedling Harvest Parameters } \\
\hline Rate & Method & & Fresh Weight & Dry Weight & Establishment \\
\hline ---- mt/ha ---- & & & ---- g/plant ---- & ---- g/plant ---- & ---- \% ---- \\
\hline 0 & NA & No & $1341.4 \mathrm{a}^{\mathrm{z}}$ & $114.3 \mathrm{a}$ & $88.7 \mathrm{~b}$ \\
\hline 2.25 & Solid & No & $27.7 \mathrm{~d}$ & $3.2 \mathrm{~d}$ & $2.8 \mathrm{e}$ \\
\hline 2.25 & Banded & No & $262.7 \mathrm{c}$ & $34.4 \mathrm{bc}$ & $28.2 \mathrm{c}$ \\
\hline 4.5 & Solid & No & $0 \mathrm{~d}$ & $0 \mathrm{~d}$ & $0.0 \mathrm{e}$ \\
\hline 4.5 & Banded & No & $0 \mathrm{~d}$ & $0 \mathrm{~d}$ & $0.0 \mathrm{e}$ \\
\hline 0 & NA & Yes & $1251.1 \mathrm{a}$ & $124.0 \mathrm{a}$ & $100.0 \mathrm{a}$ \\
\hline 2.25 & Solid & Yes & $55.8 \mathrm{~d}$ & $7.6 \mathrm{~cd}$ & $7.0 \mathrm{e}$ \\
\hline 2.25 & Banded & Yes & $507.4 \mathrm{~b}$ & $57.7 \mathrm{~b}$ & $38.0 \mathrm{c}$ \\
\hline 4.5 & Solid & Yes & $40.4 \mathrm{~d}$ & $5.4 \mathrm{~cd}$ & $1.4 \mathrm{e}$ \\
\hline 4.5 & Banded & Yes & $254.8 \mathrm{c}$ & $26.4 \mathrm{~cd}$ & $18.3 \mathrm{~d}$ \\
\hline
\end{tabular}

Note. ${ }^{\mathrm{z}}$ Means in a column followed by the same lower case letter are not significantly different at $\mathrm{P} \leq 0.05$, ANOVA.

\subsubsection{Squash}

Squash seedling establishment and growth followed the same general trend as cantaloupe (Table 6) and cucumber (Table 7) in their response to MSM applications, application method, and incorporation (Table 8). As the MSM application rate increased, all the harvest parameters decreased, and MSM solid application had lower values than their corresponding application rate and incorporation method (Table 8).

Table 8. Impact of mustard seed meal applications (MSM) on squash seedling growth and establishment as affected by mustard seed meal application rates, application methods, and incorporation averaged across 2007 and 2008

\begin{tabular}{|c|c|c|c|c|c|}
\hline \multicolumn{2}{|c|}{ Application } & \multirow{2}{*}{ Incorporation } & \multicolumn{3}{|c|}{ Squash Seedling Harvest Parameters } \\
\hline Rate & Method & & Fresh Weight & Dry Weight & Establishment \\
\hline ---- mt/ha ---- & & & ---- g/plant ---- & ---- g/plant ---- & ---- \% ---- \\
\hline 0 & NA & No & $4663.8 \mathrm{a}^{\mathrm{z}}$ & $324.2 \mathrm{a}$ & $67.5 \mathrm{~b}$ \\
\hline 2.25 & Solid & No & $877.2 \mathrm{f}$ & $68.4 \mathrm{~d}$ & $8.8 \mathrm{e}$ \\
\hline 2.25 & Banded & No & $1331.67 \mathrm{e}$ & $101.0 \mathrm{c}$ & $15.0 \mathrm{de}$ \\
\hline 4.5 & Solid & No & $76.8 \mathrm{~g}$ & $6.6 \mathrm{ef}$ & $1.3 \mathrm{f}$ \\
\hline 4.5 & Banded & No & $1418.4 \mathrm{e}$ & $90.7 \mathrm{c}$ & $18.8 \mathrm{~d}$ \\
\hline 0 & NA & Yes & $4291.7 \mathrm{~b}$ & $300.0 \mathrm{a}$ & $100.0 \mathrm{a}$ \\
\hline 2.25 & Solid & Yes & $669.0 \mathrm{f}$ & $52.3 \mathrm{de}$ & $5.0 \mathrm{ef}$ \\
\hline 2.25 & Banded & Yes & $2267.8 \mathrm{c}$ & $168.0 \mathrm{~b}$ & $36.3 \mathrm{c}$ \\
\hline 4.5 & Solid & Yes & $299.6 \mathrm{~g}$ & 26.7 ef & $3.8 \mathrm{f}$ \\
\hline 4.5 & Banded & Yes & $1823 \mathrm{~d}$ & $136.8 \mathrm{~b}$ & $33.8 \mathrm{c}$ \\
\hline
\end{tabular}

Note. ${ }^{\mathrm{z}}$ Means in a column followed by the same lower case letter are not significantly different at $\mathrm{P} \leq 0.05$, ANOVA. 


\subsubsection{Watermelon}

Watermelon seedling establishment and growth (Table 9) was not as consistent as the cantaloupe (Table 6), cucumber (Table 7), and squash (Table 8) data. The MSM solid application at $2.25 \mathrm{mt} / \mathrm{ha}$, compared to banded application, produced reduced fresh and dry weights independently of the incorporation method, and watermelon establishment was reduced when incorporating MSM at $2.5 \mathrm{mt} / \mathrm{ha}$ (Table 9). When MSM was applied at $4.5 \mathrm{mt} / \mathrm{ha}$ and not incorporated, plant weights were reduced compared to the solid application when not incorporated (Table 9). When $4.5 \mathrm{mt} / \mathrm{ha}$ MSM was incorporated, only the watermelon dry weights were reduced by the solid application (Table 9). When comparing incorporation treatments for 2.5 and $4.5 \mathrm{mt} / \mathrm{ha} \mathrm{MSM}$, watermelon plant weights and establishment were reduced more when the MSM was not incorporated (Table 9).

Table 9. Impact of mustard seed meal applications (MSM) on watermelon seedling growth and establishment as affected by mustard seed meal application rates, application methods, and incorporation averaged across 2007 and 2008

\begin{tabular}{|c|c|c|c|c|c|}
\hline \multicolumn{2}{|c|}{ Application } & \multirow{2}{*}{ Incorporation } & \multicolumn{3}{|c|}{ Watermelon Seedling Harvest Parameters } \\
\hline Rate & Method & & Fresh Weight & Dry Weight & Stand \\
\hline ---- mt/ha ---- & & & ---- g/plant ---- & ---- g/plant ---- & ---- \% ---- \\
\hline 0 & NA & No & $2075.7 b^{z}$ & $191.2 \mathrm{~b}$ & $70.7 \mathrm{~b}$ \\
\hline 2.25 & Solid & No & $88.2 \mathrm{e}$ & $9.1 \mathrm{e}$ & $3.4 \mathrm{~d}$ \\
\hline 2.25 & Banded & No & $268.6 \mathrm{~cd}$ & $27.8 \mathrm{e}$ & $8.6 \mathrm{~d}$ \\
\hline 4.5 & Solid & No & $499.2 \mathrm{~d}$ & $52.8 \mathrm{~d}$ & $27.6 \mathrm{c}$ \\
\hline 4.5 & Banded & No & $81.2 \mathrm{e}$ & $11.4 \mathrm{e}$ & $8.6 \mathrm{~d}$ \\
\hline 0 & NA & Yes & $2344.6 \mathrm{a}$ & $231.9 \mathrm{a}$ & $100.0 \mathrm{a}$ \\
\hline 2.25 & Solid & Yes & $146.4 \mathrm{e}$ & $16.4 \mathrm{e}$ & $3.4 \mathrm{~d}$ \\
\hline 2.25 & Banded & Yes & $2282.6 \mathrm{a}$ & 229.9 a & $69.0 \mathrm{~b}$ \\
\hline 4.5 & Solid & Yes & $1020.7 \mathrm{c}$ & $79.9 \mathrm{~d}$ & $31.0 \mathrm{c}$ \\
\hline 4.5 & Banded & Yes & $1134.4 \mathrm{c}$ & $113.1 \mathrm{c}$ & $34.5 \mathrm{c}$ \\
\hline
\end{tabular}

Note. ${ }^{\mathrm{z}}$ Means in a column followed by the same lower case letter are not significantly different at $\mathrm{P} \leq 0.05$, ANOVA.

\section{Discussion}

\subsection{Weed Control}

\subsubsection{Broadleaf and Grass Weed Control}

As with previous MSM research (Boydston et al., 2008; Boydston et al., 2011; Earlywine et al., 2010; Wang et al., 2015), weed control typically increased as the application rate increased. The solid application of MSM generally also increased weed control compared to the banded application. These results are consistent with Boydston et al. (2008) who emphasized the importance of MSM placement near germinating weed seedlings to maximize weed control efficacy. The impact of incorporating the MSM was less important than the application method used (solid vs. banded). These results are in contrast to Boydston et al. (2008) concerning the potential impact of disturbing the soil after MSM application. As noted by Handiseni et al. (2011) and Wang et al. (2008), there appears to be greater broadleaf control compared grass control with 'IdaGold' mustard, especially when measured at the later collection dates (15 and 19 DAP). Whether the differential control of broadleaf species compared to grass species is due to dicot versus monocots, relative seed size, or dependent of the specific weed species is unknown. Sustained high (>93\%) broadleaf (cutleaf groundcherry and spiny amaranth) weed control was obtained with both application rates, and application and incorporation methods through 19 DAP, except for $4.5 \mathrm{mt} / \mathrm{ha}$ banded and not incorporated treatment. These results are in contrast to the grass (smooth crabgrass) weed control, where the levels of weed control quickly decreased as the number of days following application increased.

\subsubsection{Total Weed Control}

The total weed control data provides a promising portrait of the potential usefulness of MSM as a weed control method. In general the weed control ratings were greater than $80 \%$, even after 19 DAP. The impact of application 
and incorporation method varied across application rates without many consistent results. The best weed control treatment across evaluation dates was the $4.5 \mathrm{mt} /$ ha solid application of MSM without incorporation.

\subsubsection{Nutsedge Weed Control}

The nutsedge weed control results were largely influenced by the low percentage of nutsedge plants present $(<$ $1 \%$ ) and their uneven distribution across the experiment. Further research should investigate the impact of MSM on uniform stands of nutsedge to provide a more consistent and reliable evaluation of MSM on nutsedge growth and development.

\subsection{Cucurbit Seedling Establishment and Harvest}

The incorporated control treatment ( $0 \mathrm{mg} / \mathrm{ha} \mathrm{MSM})$ in each of the cucurbit types (cantaloupe, cucumber, squash, and watermelon) represented the best stand establishment. Also, in each seedling type the non-incorporated control treatment $(0 \mathrm{mg} / \mathrm{ha} \mathrm{MSM})$ had the second highest stand establishment, but significantly less than the incorporated control treatment (0 mg/ha MSM).

\section{Conclusions}

Although the use of MSM as a weed control method shows great promise, the application of MSM at 2.25 and 4.5 $\mathrm{mt} /$ ha severely reduced crop establishment to direct-seeded cucurbits. Boydston et al. (2011) also reported that MSM, 'IdaGold', application rates of 110,220 , and $440 \mathrm{~g} / \mathrm{m}^{2}$ severely reduced onion establishment in a greenhouse study when applied PPI, PRE or at the cotyledon stage. The current research is consistent with the application of corn gluten meal to direct-seed vegetables (black bean (Phaseolus vulgaris L.), pinto bean, cantaloupe, and watermelon by Webber et al. (2008). Further research should address banded applications of MSM with either established direct-seeded or transplanted cucurbits, or other vegetable crops in the same manner as others have done with corn gluten meal (Boydston et al., 2011; Webber \& Shrefler, 2006; Webber et al., 2007).

\section{References}

Ahrens, W. H., Cox, D. J., \& Budhwar, G. (1990). Use of the arcsine and square root transformation for subjectively determined percentage data. Weed Sci., 38, 452-458. https://doi.org/10.1017/S0043174500 056824

Boydston, R. A., Anderson, T., \& Vaughn, S. F. (2008). Mustard (Sinapis alba) seed meal suppresses weeds in container-grown ornamentals. HortScience, 43, 800-803.

Boydston, R. A., Morra, M. J., Borek, V., Clayton, L., \& Vaughn, S. F. (2011). Onion and weed response to mustard (Sinapis alba) seed meal. Weed Sci., 59(4), 546-552. https://doi.org/10.1614/WS-D-10-00185.1

Brown, J. (1997). 'IdaGold' Yellow Condiment Mustard (Sinapis alba L.) (Certificate No. 9700374). Idaho Agricultural Experiment Station. Retrieved from https:/www.uidaho.edu/research/business/tech-transfer/ plants/mustard/97-004

Ciubota-Rosie, C., Macoveanu, M., Fernández, C. M., Ramos, M. J., Pérez, A., \& Moreno, A. (2013). Sinapis alba seed as a prospective biodiesel source. Biomass and Bioenergy, 51, 83-90. https://doi.org/10.1016/ j.biombioe. 2013.01 .008

Earlywine, D. T., Smeda, R. J., Teuton, T. C., Sams, C. E., \& Xiong, X. (2010). Evaluation of oriental mustard (Brassica juncea) seed meal for weed suppression in turf. Weed Technology, 24(4), 440-445. https://doi.org/ 10.1614/WT-D-09-00058.1

Handiseni, M., Brown, J., Zemetra, R., \& Mazzola, M. (2011). Herbicidal activity of Brassicaceae seed meal on wild oat (Avena fatua), Italian ryegrass (Lolium multiflorum), redroot pigweed (Amaranthus retroflexus), and prickly lettuce (Lactuca serriola). Weed Technology, 25(1), 127-134. https://doi.org/10.1614/WT-D10-00068.1

Haramoto, E. R., \& Gallandt, E. R. (2005). Brassica cover cropping: II. Effects on growth and interference of green bean (Phaseolus vulgaris) and redroot pigweed (Amaranthus retroflexus). Weed Sci., 53, 702-708. http://dx.doi.org/10.1614/WS-04-163R.1

Hoagland, L., Carpenter-Boggs, L., Reganold, J. P., \& Mazzola, M. (2008). Role of native soil biology in Brassicaceous seed meal-induced weed suppression. Soil Biology and Biochemistry, 40(7), 1689-1697. https://doi.org/10.1016/j.soilbio.2008.02.003 
Idikó, S. G., Klára, K. A., Marianna, T. M., Ágnes, B., Zsuzsanna, M. B., \& Bálint, C. (2006). The effect of radio frequency heat treatment on nutritional and colloid-chemical properties of different white mustard (Sinapis alba L.) varieties. Innovative Food Science \& Emerging Technologies, 7(1), 74-79. https://doi.org/10.1016/ j.ifset.2005.06.001

Kobayashi, K. (2004). Factors affecting phytotoxic activity of allelochemicals in soil. Weed Biology and Management, 4, 1-7. https://doi.org/10.1111/j.1445-6664.2003.00112.x

McDade, M. C., \& Christians, N. E. (2000). Corn gluten meal-a natural preemergence herbicide: Effect on vegetable seedling survival and weed cover. Amer. J. Altern. Agricult., 15(4), 189-191. https://doi.org/ $10.1017 / \mathrm{S} 0889189300008778$

Motes, J., Roberts, W., Damicone, J., Edelson, J., \& Duthie, J. (2008). Squash and pumpkin production. Oklahoma Coop. Ext. Serv. Fact Sheet HLA-6026.

Pimental, D., McNair, S., \& Janecka, J. (2001). Economic and environmental threats of alien plant, animal and microbe invasions. Agric. Ecosys. Environ., 84, 1-20. https://doi.org/10.1016/S0167-8809(00)00178-X

Rice, E. L. (1984). Allelopathy (2nd ed., p. 422). Academic Press, Orlando, Florida.

Walz, E. (2011). Third biennial national organic farmer's survey (p. 124). Santa Cruz, CA: Organic Farming Research Foundation.

Wang, X., Gu, M., Niu, G., \& Baumann, P. A. (2015). Herbicidal activity of mustard seed meal (Sinapis alba 'IdaGold'and Brassica juncea 'Pacific Gold') on weed emergence. Industrial Crops and Products, 77, 1004-1013. https://doi.org/10.1016/j.indcrop.2015.09.070

Webber, C. L. III, \& Shrefler, J. W. (2006). Corn gluten meal applicator for weed control in organic vegetable production. J. Vegetable Crop Production, 12(4), 19-26. 2006. https://doi.org/10.1300/J484v12n04_03

Webber, C. L. III, \& Shrefler, J. W. (2008). Impact of corn gluten meal on direct-seeded vegetable seedling establishment. International J. of Vegetable Sci., 13(3), 5-15. https://doi.org/10.1300/J512v13n03_02

Webber, C. L. III, Shrefler, J. W., \& Taylor, M. J. (2007). Corn gluten meal as an alternative weed control option for spring-transplanted onions. International J. of Veg. Sci., 13(3), 17-33. https://doi.org/10.1300/J512v13 n03_03

Zimdahl, R. L. (2002). My view. Weed Sci., 50, 687. https://doi.org/10.1614/0043-1745(2002)050[0137:MV] 2.0.CO;2

\section{Copyrights}

Copyright for this article is retained by the author(s), with first publication rights granted to the journal.

This is an open-access article distributed under the terms and conditions of the Creative Commons Attribution license (http://creativecommons.org/licenses/by/4.0/). 